UNIVERSIDADE DE SÃO PAULO

MUSEU DE ZOOLOGIA

\title{
Ernesto Aranda Pedroso
}

\section{Systematics of Quaternary Squamata from Cuba}

\section{Sistemática dos Squamata Quaternários de Cuba}

Corrected version

\author{
Dissertation presented to the \\ PostGraduate Program of the \\ Museu de Zoologia da \\ Universidade de São Paulo to \\ obtain the degree of Master of \\ Science (Systematics, Animal \\ Taxonomy and Biodiversity)
}

Advisor: Hussam El Dine Zaher Co-Advisor: Luis Manuel Díaz Beltrán 


\section{Resumo}

Aranda E. (2019). Sistemática dos Squama do Quaternário de Cuba. (Dissertação de Mestrado). Museu de Zoologia, Universidade de São Paulo, São Paulo.

A paleontologia de répteis no Caribe é um tema de grande interesse para entender como a fauna atual da área foi constituída a partir da colonização e extinção dos seus grupos. O maior número de fósseis pertence a Squamata, que vá desde o Eoceno até nossos dias. O registro abrange todas as ilhas das Grandes Antilhas, a maioria das Pequenas Antilhas e as Bahamas. Cuba, a maior ilha das Antilhas, tem um registro fóssil de Squamata relativamente escasso, com 11 espécies conhecidas de 10 localidades, distribuídas no oeste e centro do país. No entanto, existem muitos outros fósseis depositados em coleções biológicas sem identificação que poderiam esclarecer melhor a história de sua fauna de répteis. Um total de 328 fósseis de três coleções paleontológicas foi selecionado para sua análise, a busca de características osteológicas diagnosticas do menor nível taxonômico possível, e compará-los com outros fósseis e espécies recentes. No presente trabalho, o registro fóssil de Squamata é aumentado, tanto em número de espécies quanto em número de localidades. O registro é estendido a praticamente todo o território cubano. Restos fósseis pertencentes a espécies relatadas anteriormente são confirmados, como Leiocephalus cubensis, L. carinatus, Tarentola americana, Chilabothrus angulifer e Cubophis cantherigerus. Fósseis de Amphisbaena, Pholidoscelis auberi e Leiocephalus macropus são descritos pela primeira vez. Além de outros fósseis pertencentes aos gêneros Tarentola, Leiocephalus e Chilabothrus, mas diferentes das espécies que atualmente habitam o arquipélago. Esses resultados mostram que o registro fóssil de Squamata em Cuba é mais amplo do que era considerado anteriormente, apesar de ser composto de fósseis muito frágeis e pequenos, com pouco potencial para a fossilização. Para a paleontologia de Squamata, a descrição de novos táxons e registro de novas localidades em Cuba, são os primeiros passos para estudos mais integradores sobre diversidade biológica, evolução, biogeografia, paleoambiente entre outros que contribuam ao entendimento da fauna na região do Caribe.

Palavras-chave: Antilhas. Neógeno. Lagartos. Serpentes. Fóssil. 


\section{Abstract}

Aranda E. (2019). Systematics of Quaternary Squamata from Cuba. (Master dissertation). Museum of Zoology, University of São Paulo, São Paulo.

The paleontology of reptiles in the Caribbean is a topic of great interest to understand how the current fauna of the area was constituted from colonization and extinction of their groups. The largest number of fossils belongs to Squamata, ranging from the Eocene to our days. The registry covers all the islands of the Greater Antilles, most of the Lesser Antilles, and of the Bahamas. Cuba, the largest island of the Antilles, has a relatively sparse Squamata fossil record, with 11 known species from 10 locations, distributed in the West and Center of the Country. However, there are many other fossils deposited in biological collections without identification that could better clarify the history of their reptile fauna. A total of 328 fossils from three paleontological collections were selected for their analysis, searching osteological characteristics that would serve to diagnose them at the lowest possible taxonomic level, and compare them with other fossils and recent species. In the present work, the Squamata fossil record is increased, both in the number of species and in the number of localities. The registry is extended to practically all of the Cuban territory. Fossil remains belonging to previously reported species are confirmed, such as Leiocephalus cubensis, L. carinatus, Tarentola americana, Chilabothrus angulifer, and Cubophis cantherigerus. Fossils of Amphisbaena, Pholidoscelis auberi, and Leiocephalus macropus are described for the first time. Besides, other fossils belonging to the genera Tarentola, Leiocephalus, and Chilabothrus but different from the species that currently inhabit the archipelago, are described. These results show that the Squamata fossil record in Cuba is broader than what was previously considered, despite being composed of very fragile and small fossils with little potential for fossilization. For the paleontology of Squamata the description of new taxa and record of new localities in Cuba, are the first steps for more integrating studies on biological diversity, evolution, biogeography, paleoenvironment among others that contribute to the understanding of the fauna in the Caribbean region.

Key words: Antilles. Neogene. Lizard. Snake. Fossil. 


\section{Introduction}

The Antilles are recognized as an exceptional biogeographic scenario (Losos \& Ricklefs, 2010), by the extinction, colonization and adaptive radiations experienced by some of their zoological groups(Hedges, 1989; Pregill \& Olson, 1981; Silva, Duque, \& Díaz-Franco, 2007). From 40 million years ago there are permanent islands in the Antillean region (Iturralde-Vinent, 2005), and since then the evolutionary history of the lineages has begun (Silva et al., 2007). The main hypotheses for the arrival of terrestrial fauna are: (1) the formation of Gaarlandia during the Eocene-Oligocene transition, a chain of islands that functioned as a filter for the passage of species (Iturralde-Vinent, 2006); and (2) oceanic dispersion by rafting or intense meteorological phenomena (Buskirk, 1985; Hedges, 2001). However, there are some faunal examples for the Gaarlandia existence (Alonso, Crawford, \& Bermingham, 2012), until now, no geologic data demonstrated the existence of a continuing land between the Birds Arc and the Lesser Antilles (Ali, 2012).

Squamata reptiles may have used either of these two routes to colonize the Antilles and irradiate. Molecular data accord with geological data, sustaining a Cenozoic arrival to the Antilles for all Squamata groups (Gamble et al., 2011; Hedges, 1996), except for the endemic Cuban genus Cricosaura. This last genus is a very ancient relic, possibly from the Upper Cretaceous, although controversial because so far no fossil remains were found on any of the islands (Gauthier, Kearney, Maisano, Rieppel, \& Behlke, 2012; Savage, 1964). The genera Cyclura and Leiocephalus probably arrived during mid-Cenozoic, while the other genera of Squamata colonized the region more recently (Hedges, 2006).

The record of Squamata fossils has very good studies in some islands like Hispaniola, Puerto Rico, Antigua, Guadalupe Islands, and some of the Bahamas Bank (Bochaton et al., 2015; Etheridge, 1965; Pregill, 1981; Pregill, Steadman, Olson, \& Grady, 1988; Pregill, Steadman, \& Watters, 1994; Steadman et al., 2015). Other islands of the Antilles are still much less studied, or not studied at all, concearning their paleofauna of Squamata. Oldest fossils are from the Miocene of the Dominican Republic amber (Daza \& Bauer, 2012; Queiroz, Chu, \& Losos, 1998) 
and from a Puerto Rican lignithic clayey (MacPhee \& Wyss, 1990). These fossils give us some understanding about times and forms of colonization in the Antillean territories.

In the Antilles, Cuba is the largest island, with an approximate area of $110 \mathrm{~km}^{2}$ and a maximum elevation of 1974 m.s.I (National Office of Statistic and Information, 2017). The autochthonous fauna of Cuban lizards are grouped into eight families, nine genera, and 99 species (RodríguezSchettino et al., 2013; Uetz, Freed, \& Hošek, 2018). The two most diverse families are Dactyloidae with 64 species, all belonging to the genus Anolis (95.3\% of endemism) and Sphaerodactylidae (22 species, $86.3 \%$ of endemism), composed of the genera Sphaerodactylus, and Aristelliger. Snakes are grouped into four families, nine genera, and 42 species. The most diverse families are Tropidophiidae (16 species, all endemic) and Typhlopidae (12 endemic species and 1 introduced). While amphisbaenians are grouped into two families, Amphisbaenidae with three species of the genus Amphisbaena, and Cadeidae, with two species of the genus Cadea (Rodríguez-Schettino et al., 2013; Uetz et al., 2018). This last family is endemic.

All known fossil records of Squamata are from the Pleistocene-Late Holocene age, mainly associated to cave deposits (Consuegra, 2014). So far, registered species form the western and central part of the country are Anolis lucius, A. equestris, A. porcatus, A. luetogularis, A. chamaleonides, Tarentola americana, Leiocephalus cubensis, L. carinatus, Cyclura nubila, Chilabothrus angulifer, e Cubophis cantherigerus (Arredondo, 1997; Arredondo \& Villavicencio, 2004; Brattstrom, 1958; Jiménez, Condis, \& García, 2005; Jiménez \& Valdés, 1995; Koopman \& Ruibal, 1955; Orihuela, 2012; Salgado, Calvache, Macphee, \& Gould, 1992; Varona \& Arredondo, 1979), which represents 7.5\% of the extant Cuban Squamata autochthonous fauna (Torres, Rodríguez-Cabrera, \& Romero, 2017).

So far, there is not a study dedicated to this fossil group. The papers in which fossil species of Squamata are reported, mention them as an associated fauna of fossil mammals and birds (Arredondo, 1997; Jiménez et al., 2005; Koopman \& Ruibal, 1955; Orihuela, 2012; Varona \& Arredondo, 1979), whithout a properly description, or images for illustration.

The lack of effort and specialists in this field limits the correct identification of the species, or in the worst of cases, leave the piece indeterminate (Pregill, 1992). So far, the method used in Cuban fossils is the empirical comparison with current species, without verify all the 
characters that could help to identify the species. In addition, there is a poor representation of Cuban species in osteological collections, which can lead to erroneous assignment of a character to a species given that the range of variation for a character is deduced from only one, or a few individuals (Pregill, 1992). Therefore, studies of paleoenvironment (Arredondo \& Villavicencio, 2004), biological diversity (Consuegra, 2014; Rodríguez-Schettino, 2003), and extinctions (Díaz-Franco, 2004; Pregill \& Olson, 1981) are incomplete without a good understanding of Squamata paleofauna.

In this work, we propose to perform a detailed description of the Quaternary fossil remains of Squamata, based on defined osteological characters; and conduct a survey of the Cuban fossil record. 


\section{Conclusions}

Based on the osteological descriptions and the geographical location of the records, we reached the following conclusions

- Detailed descriptions of frontal, parietal, occipital, maxillae, dentaries, articulatesurangular complexes, vertebrae, and pelvis of Cuban Squamata fossils are provided, using characters described in the scientific literature.

- Six genera and seven species were identified.

- The genera Amphisbaena and Pholidoscelis are reported by the first time in the fossil record of Cuba. Amphisbaena based on a vertebra of the middle of the body, and Pholidoscelis from frontals, parietals, maxillae, dentaries, articular-surangular complexes, and pelves.

- The presence in the fossil record of species such as Tarentola americana, Leiocephalus cubensis, L. carinatus, Chilabothrus angulifer, and Cubophis cantherigerus is confirmed, with descriptions of new fossilized bones.

- New records of species not present in Cuba are described. It is necessary to compare with other Antillean and continental species to see which species they belong to.

- From the genus Leiocephalus, two frontals, and a dentary that does not coincide with the living species of the genus are described.

- From the genus Tarentola, two parietals and two articular-surangular complexes are described with forms different from those currently present in Cuba.

- From the genus Chilabothrus, a quadrate and two compound bones are described, distinct even of known Antillean species.

- The number of reported localities with Squamata fossil remains was increased from 10 known to 19.

- The Squamata fossil record was extended to practically the whole country, by including one locality in Santiago de Cuba and another in Isla de la Juventud.

- The localities of fossil remains coincide with the current distribution of living species. 


\section{References}

Ali, Jason R. 2012. "Colonizing the Caribbean: Is the GAARlandia Land-Bridge Hypothesis Gaining a Foothold?" Journal of Biogeography 39(3): 431-33.

Alonso, Roberto, Andrew J. Crawford, and Eldredge Bermingham. 2012. "Molecular Phylogeny of an Endemic Radiation of Cuban Toads (Bufonidae: Peltophryne) Based on Mitochondrial and Nuclear Genes." Journal of Biogeography 39(3): 434-51.

Aranda, Ernesto. 2019. "Systematic of Quaternary Squamata from Cuba." Zoology Museum, São Paulo University.

Arredondo, Carlos A. 1997. "Composición de La Fauna de Vertebrados Terrestres Extintos Del Cuaternario de Cuba." Revista Electrónica Órbita Científica 2(8): 1-14.

Arredondo, Carlos A., and R Villavicencio. 2004. "Tafonomía Del Depósito Arqueológico Solapa Del Megalocnus En EI NE de Villa Clara, Cuba." Revista de Biología 18(2): 160-70.

Benites, João Paulo de Almeida. 2015. "Estudio Comparativo de Restos Fósseis e Recentes de Amphisbaenia. Abordagens Filogenéticas, Paleoecológicas, Paleobiogeográficas." Master dissertation. Paulista State University.

Blain, Hugues Alexandre, José Ignacio Canudo, Gloria Cuenca-Bescós, and Nieves LópezMartínez. 2010. "Amphibians and Squamate Reptiles from the Latest Maastrichtian (Upper Cretaceous) of Blasi 2 (Huesca, Spain)." Cretaceous Research 31(4): 433-46.

Bochaton, Corentin et al. 2015. "Fossil and Subfossil Herpetofauna from Cadet 2 Cave (MarieGalante, Guadeloupe Islands, F. W. I.): Evolution of an Insular Herpetofauna since the Late Pleistocene." Comptes Rendus - Palevol 14(2): 101-10.

- - - 2017. "Evolution, Diversity and Interactions with Past Human Populations of Recently Extinct Pholidoscelis Lizards (Squamata: Teiidae) from the Guadeloupe Islands (French West-Indies)." Historical Biology (DOI: 10.1080/08912963.2017.1343824).

Böhme, W. 1984. "Erstfund Eines Fossilen Kugelfinger-Gecko (Sauria: Gekkonidae: Sphaerodactylinae) Aus Dominikanischen Bern-Stein Der Oligozan von Hispaniola, Antillen." Salamandra 20: 212-20.

Bolet, Arnau et al. 2014. "An Amphisbaenian Skull from the European Miocene and the Evolution of Mediterranean Worm Lizards." PLOS ONE 9(6).

Brattstrom, Bayard H. 1958. "More Fossil Reptiles from Cuba." Herpetologica 13: 278.

Buskirk, Ruth E. 1985. "Zoogeographic Patterns and Tectonic History of Jamaica and the Northern Caribbean." Journal of Biogeography 12(5): 445-61.

Camolez, Tatiana, and Hussam Zaher. 2010. "Levantamento, Identificação e Descrição Da Fauna de Squamata Do Quaternário Brasileiro (Lepidosauria)." Arquivos de Zoologia 41: 
$1-96$.

Čerňanský, Andrej, Marc louis Augé, and Jean-claude Rage. 2015. “A Complete Mandible of a New Amphisbaenian Reptile (Squamata, Amphisbaenia) from the Late Middle Eocene (Bartonian, Mp 16) of France." Journal of Vertebrate Paleontology 35(1): e902379.

Čerňanský, Andrej, and Krister T. Smith. 2018. "Eolacertidae: A New Extinct Clade of Lizards from the Palaeogene; with Comments on the Origin of the Dominant European Reptile Group-Lacertidae." Historical Biology 30(7): 994-1014.

Conrad, Jack L. 2008. "Phylogeny and Systematics of Squamata (Reptilia) Based on Morphology." Bulletin American Museum of Natural History 310(310): 182.

Consuegra, Reinaldo Rojas. 2014. "Columna Ilustrada Del Registro Macrofósil de Cuba." Anuario de la Sociedad Cubana de Geología 2: 13-18.

Cope, E. D. 1862. "On the Genera Panolopus, Centropyx, Aristelliger and Sphaerodactylus." Proceedings of the Academy of Natural Sciences of Philadelphia 13: 494-500.

Daza, Juan D., Virginia Abdala, Richard Thomas, and Aaron M Bauer. 2008. "Skull Anatomy of the Miniaturized Gecko Sphaerodactylus Roosevelti (Squamata: Gekkota)." Journal of Morphology 269: 1340-64.

Daza, Juan D., Aaron M. Bauer, Philipp Wagner, and Wolfgang Böhme. 2013. "A Reconsideration of Sphaerodactylus Dommeli Böhme, 1984 (Squamata: Gekkota: Sphaerodactylidae), a Miocene Lizard in Amber." Journal of Zoological Systematics and Evolutionary Research 51(1): 55-63.

Daza, Juan D., and Aaron M Bauer. 2012. “A New Amber-Embedded Sphaerodactyl Gecko from Hispaniola, with Comments on Morphological Synapomorphies of the Sphaerodactylidae." Breviora 529: 1-28.

Díaz-Franco, Stephen. 2004. "Análisis de La Extinción de Algunos Mamíferos Cubanos, Sobre La Base de Evidencias Paleontológicas y Arqueológicas." Revisa Biología 18(2): 147-54.

Díaz, Luis M., and S. Blair Hedges. 2008. "A New Gecko of the Genus Tarentola (Squamata: Gekkonidae) from Eastern Cuba." Zootaxa 1743: 43-52.

Domínguez, Michel, and Luis Moreno. 2006. "Alsophis Cantherigerus. Size Record." Herpetological Review 37(3): 349.

Duméril, A. M. C., and G. Bibron. 1844. 16 Erpetologie Générale Ou Histoire Naturelle Complete Des Reptiles. Paris: Encyclopédique Roret.

Estes, Richard, K Queiroz, and Jacques A. Gauthier. 1988. "Phylogenetic Relationships within Squamata." In Phylogenetic Relationships of the Lizard Families, eds. R Estes and G Pregill. Stanford: Stanford University Press, 119-281.

Etheridge, Richard. 1959. "The Relationships of the Anoles (Reptilia: Sauria: Iguanidae) an Interpretation Based on Skeletal Morphology." University of Michigan. 
- - . 1964. "Late Pleistocene Lizards from Barbuda, British West Indies." Bulletin of the Florida State Museum 9(2): 43-75.

- - . 1965. "Fossil Lizards from the Dominican Republic." Quarterly Journal of The Florida Academy of Sciences 27-28: 83-105.

- - . 1966a. "An Extinct Lizard of the Genus Leiocephalus from Jamaica." Quaterly Journal of the Florida Academy of Sciences 29: 47-59.

- - . 1966b. "Pleistocene Lizards from New Providence." Quarterly Journal of The Florida Academy of Sciences 28: 349-58.

Etheridge, Richard, and Kevin de Queiroz. 1988. "A Phylogeny of Iguanidae." In Phylogenetic Relationships of the Lizard Families. Essays Commemorating Charles L. Camp, eds. R Estes and G Pregill. Stanford, C.A: Stanford Univ. Press., 283-367.

Evans, Susan E. 2008. "The Skull of Lizards and Tuatara." In Biology of the Reptilia, eds. Carl Gans, Abbot S. Gaunt, and Kraig Adler. Ithaca: Society for the Study of Amphibians and Reptiles, 1-347.

Fernández-Milera, J, and M Correoso. 2003. "Los Moluscos Terrestres y Fluviales de La Isla de La Juventud." Cocuyo 13: 15-18.

Frazetta, T H. 1959. "Studies on the Morphology and Function of the Skull in the Boidae (Serpentes). Part I. Cranial Differences between Python Sebae and Epicrates Cenchris." Bulletin of the Museum of Comparative Zoology 119(8): 453-72.

Frost, Darrel R, Richard E Etheridge, Daniel Janies, and Tom A Titus. 2001. "Total Evidence, Sequence Alignment, Evolution of Polychrotid Lizards, and a Reclassification of the Iguania (Squamata: Iguania)." American Museum Novitates 3343(3343): 38pp.

Gamble, T. et al. 2011. "Coming to America: Multiple Origins of New World Geckos." Journal of Evolutionary Biology 24: 231-44.

Gamble, T., Aaron M. Bauer, Eli Greenbaum, and Todd R. Jackman. 2008. "Out of the Blue: A Novel, Trans-Atlantic Clade of Geckos (Gekkota, Squamata)." Zoologica Scripta 37(4): 355-66.

Gauthier, Jacques A. et al. 2012. "Assembling the Squamate Tree of Life: Perspectives from the Phenotype and the Fossil Record Assembling the Squamate Tree of Life : Perspectives from the Phenotype and the Fossil Record." Bulletin of the Peabody Museum of Natural History 53(1): 3-308.

Goicoechea, Noemí et al. 2016. "Molecular Systematics of Teioid Lizards (Teioidea/Gymnophthalmoidea: Squamata) Based on the Analysis of 48 Loci under TreeAlignment and Similarity-Alignment." Cladistics 32(6): 624-71.

Gray, E. J. 1831. "A Synopsis of the Species of Class Reptilia." In The Animal Kingdom Arranged in Conformity with Its Organisation, ed. George Cuvier. London: Whittaker, 591.

Griffing, Aaron H., Juan D. Daza, Jonathan C. DeBoer, and Aaron M. Bauer. 2018. 
"Developmental Osteology of the Parafrontal Bones of the Sphaerodactylidae." Anatomical Record 301(4): 581-606.

Harvey, Michael B, Gabriel N Ugueto, and Ronald L Gutberlet. 2012. "Review of Teiid Morphology with a Revised Taxonomy and Phylogeny of the Teiidae (Lepidosauria: Squamata)." Zootaxa 3459: 1-156.

Hecht, Max Knobler. 1951. "Fossil Lizards of the West Indian Genus Aristelliger (Gekkonidae)." American Museum Novitates 1538: 1-33.

Hedges, S. Blair. 1989. "Evolution and Biogeography of West Indian Frogs of the Genus Eleutherodactylus: Slow Evolving Loci and the Major Groups." In Biogeography of the West Indies: Past, Present, and Future, ed. C A Woods. Gainesville, Florida: Sand Hill Crane Press, 305-370.

- - . 1996. "Historical Biogeography of West Indian Vertebrates." Annu. Rev. Ecol. Syst. 27: 163-96.

- - . 2001. "Biogeography of the West Indies: An Overview." In Biogeography of the West Indies: Patterns and Perspectives, eds. C A Woods and F E Sergile. Boca Raton: CRC Press, 15-33.

Hedges, S. Blair, Arnaud Couloux, and Nicolas Vidal. 2009. "Molecular Phylogeny, Classification, and Biogeography of West Indian Racer Snakes of the Tribe Alsophiini (Squamata, Dipsadidae, Xenodontinae)." Zootaxa 2067: 1-28.

Hsiou, Annie Schmaltz. 2007. "A New Teiidae Species (Squamata, Scincomorpha) from the Late Pleistocene of Rio Grande Do Sul State, Brazil." Revista Brasileira de Paleontologia 10(3): 181-94.

Ikeda, Tadahiro. 2007. "A Comparative Morphological Study of the Vertebrae of Snakes Occurring in Japan and Adjacent Regions A Comparative Morphological Study of the Vertebrae of Snakes Occurring in Japan and Adjacent Regions." Current Herpetology 26(1): 13-34.

Instituto Cubano de Cartografía y Catastro. 1957. "Cartografía Topográfica de Cuba 1:50 000."

Iturralde-Vinent, Manuel A. 2005. "La Paleogeografía Del Caribe y Sus Implicaciones Para La Biogeografía Histórica." Revista del Jardín Botánico Nacional 26: 49-78.

- - . 2006. "Meso-Cenozoic Caribbean Paleogeography: Implications for the Historical Biogeography of the Region." International Geology Review 48: 791-827.

Jiménez, Osvaldo, Marjorie M Condis, and Elvis García. 2005. "Vertebrados Post-Glaciales En Un Residuario Fósil de Tyto Alba Scopoli (Aves: Tytonidae), En El Occidente de Cuba." Revista Mexicana de Mastozoología 9: 85-112.

Jiménez, Osvaldo, and P Valdés. 1995. "Los Vertebrados Fósiles de La Cueva Del Indio, San José La Lajas, Habana, Cuba." Congreso Internacional 55 Aniversario de la Sociedad Espeleológica de Cuba: 62-63. 
Kearney, Maureen. 2003. "Systematics of the Amphisbaenia (Lepidosauria: Squamata) Based on Morphological Evidence from Recent and Fossil Forms." Herpetological Monographs 17(2003): 1-74.

Kluge, Arnold. 1989. "A Concern for Evidence and a Phylogenetic Hypothesis of Relationships Among Epicrates (Boidae, Serpentes)." Systematic Zoology 38(1): 7-25.

- - . 1991. "Boine Snake Phylogeny and Research Cycles." Miscellaneous Publications Museum of Zoology, University of Michigan 178: 1-58.

Koopman, Karl F, and Rodolfo Ruibal. 1955. "Cave Fossil Vertebrates from Camagüey, Cuba." Breviora, Museum of Comparative Zoology 46: 1-8.

Losos, Jonathan B, and Robert E Ricklefs. 2010. The Theory of Island Biogeography Revisited. Oxford: Princeton University Press.

MacPhee, R D E, and Andre R Wyss. 1990. "Oligo-Miocene Vertebrates from Puerto Rico, with a Catalog of Localities." American Museum Novitates 2965: 1-45.

Mancina, Carlos A., and Daryl D. Cruz. 2017. Diversidad Biológica de Cuba: Métodos de Inventario, Monitoreo y Colecciones Biológicas. eds. C. A. Mancina and D. D. Cruz Flores. La Habana: AMA.

Mandriola, Local Fauna, Massimo Delfino, Salvador Bailon, and Gaetano Pitruzzella. 2011. "The Late Pliocene Amphibians and Reptiles from 'Capo Mannu D1 Local Fauna' (Mandriola, Sardinia, Italy)." Geodiversitas 33(2): 357-82.

Mead, Jim I., and David W. Steadman. 2017. "Late Pleistocene Snakes (Squamata: Serpentes) from Abaco, The Bahamas." Geobios 50(3): 431-40.

Montero, Ricardo, Virginia Abdala, Silvia Moro, and Gabriela Gallardo. 2004. "Atlas de Tupinambis Rufescens (Squamata: Teiidae). Anatomía Externa, Osteología y Bibliografía." Cuadernos de Herpetologia 18(1): 17-32.

National Office of Statistic and Information. 2017. Anuario Estadístico de Cuba 2016. Capítulo 1: Territorio. Habana.

Noble, G K. 1921. "The Bony Structure and Phyletic Relations of the Sphaerodactylus and Allied Lacertilian Genera, with the Description of a New Genus." American Museum Novitates 4: 1-16.

Oelrich, Thomas M. 1956. "The Anatomy of the Head of Ctenosaura Pectinata (Iguanidae)." Miscellaneous Publication Museum of Zoology, University of Michigan 94: 1-122.

Orihuela, Johanset. 2010. "Late Holocene Fauna from a Cave Deposit in Western Cuba: PostColumbian Occurrence of the Vampire Bat Desmodus Rotundus (Phyllostomidae: Desmodontinae)." Caribbean Journal of Science 46(2-3): 297-312.

Pregill, Gregory K. 1981. "Late Pleistocene Herpetofaunas from Puerto Rico." Miscellaneous publication, University of Kansas, Museum of Natural History. 71: 1-72. 
- - . 1992. "Systematics of the West Indian Lizard Genus Leiocephalus (Squamata: Iguania: Tropiduridae)." The University of Kansas Museum of Natural History, Miscellaneous Publications (84): 1-69.

- - . 1999. "Eocene Lizard from Jamaica." Herpetologica 55(2): 157-61.

Pregill, Gregory K., and Storrs L Olson. 1981. "Zoogeography of West Indian Vertebrates in Relation to Pleistocene Climatic Cycles." Ann. Ret. Ecol. Syst. 12: 75-98.

Pregill, Gregory K., David Steadman, Storrs Olson, and Frederick Grady. 1988. "Late Holocene Fossil Vertebrates from Burma Quarry, Antigua, Lesser Antilles." Smithsonian Contributions to Zoology 463: 1-27.

Pregill, Gregory K., David W. Steadman, and D. R. Watters. 1994. "Late Quaternary Vertebrate Faunas of the Lesser Antilles: Historical Components of Caribbean Biogeography." Bulletin of Canergie Museum of Natural History 30: 1-51.

Presch, William F. 1970. PhD "The Evolution of Macroteiid Lizards: An Osteological Interpretation." University of Southern California.

- - . 1974. "A Survey of the Dentition of the Macroteiid Lizards (Teiidae: Lacertilia)." Herpetologica 30(4): 344-49.

Queiroz, Kevin D E, Ling-ru Chu, and Jonathan B Losos. 1998. "A Second Anolis Lizard in Dominican Amber and the Systematics and Ecological Morphology of Dominican Amber Anoles." American Museum Novitates 3249: 1-23.

Rage, Jean Claude, Martin Pickford, and Brigitte Senut. 2013. "Amphibians and Squamates from the Middle Eocene of Namibia, with Comments on Pre-Miocene Anurans from Africa." Annales de Paleontologie 99(3): 217-42.

Reynolds, Graham, Alberto Puente-Rolón, Joseph Burgess, and Brian Baker. 2018. "Rediscovery and a Redescription of the Crooked-Acklins Boa, Chilabothrus Schwartzi (Buden, 1975), Comb. Nov." Breviora 558(1): 1-16.

Reynolds, R Graham et al. 2013. "Molecular Phylogeny and Historical Biogeography of West Indian Boid Snakes (Chilabothrus)." Molecular Phylogenetics and Evolution 68(3): 46170.

Reynolds, R Graham, Alberto R. Puente-Rolón, et al. 2016. "Discovery of a Remarkable New Boa from the Conception Island Bank, Bahamas." Breviora 549(1): 1-19.

Reynolds, R Graham, David C Collar, et al. 2016. "Ecological Specialization and Morphological Diversification in Greater Antillean Boas." Evolution 70(8): 1882-1895.

Rieppel, O. 1980. "Green Anole in Dominican Amber." Nature 286: 486-87.

Rodríguez-Schettino, Lourdes. 2003. Anfibios y Reptiles de Cuba. eds. Lourdes RodríguezSchettino and Julio J. Larramendi. La Habana: Instituo de Ecología y Sistemática.

- - . 2013. "Reptiles of Cuba: Checklist and Geographic Distributions." Smithsonian 
Herpetological Information Service 144: 1-96.

Rohlf, F James. 2001. TpsDig - Thin Plate Spline Digitizer, Version 2.11. New York: State University of New York at Stony Brook.

Russell, Anthony P., and Aaron M. Bauer. 2008. "The Appendicular Locomotor Apparatus of Sphenodon and Normal-Limbed Squamates." In Biology of the Reptilia 21, eds. Carl Gans, Abbot S. Gaunt, and Kraig Adler. Ithaca: Society for the Study of Amphibians and Reptiles, $1-465$.

Salgado, Efren S. Jaimez, Divaldo Gutiérrez Calvache, Ross D. E. Macphee, and Gina C. Gould. 1992. "The Monkey Caves of Cuba." Cave Science 19(1): 25-28.

Savage, Jay M. 1964. "Studies on the Lizard Family Xantusiidae. V. The Cuban Night Lizard, Cricosaura Typica Gundlach and Peters." Copeia 1964(3): 536-42.

Scanferla, Carlos A., Ricardo Montero, and Federico L. Agnolín. 2006. "The First Fossil Record of Amphisbaena Heterozonata from the Late Pleistocene of Buenos Aires Province, Argentina." South American Journal of Herpetology 1(2): 138-42.

Scanferla, Carlos A., Krister T. Smith, and Stephan F. K. Schaal. 2016. "Revision of the Cranial Anatomy and Phylogenetic Relationships of the Eocene Minute Boas Messelophis Variatus and Messelophis Ermannorum (Serpentes, Booidea)." Zoological Journal of the Linnean Society 176(1): 182-206.

Schwartz, A., and C.J. McCoy. 1970. "A Systematic Review of Ameiva Auberi Cocteau (Reptilia, Teiidae) in Cuba and the Bahamas. I. The Cuban Subspecies. II: The Bahamian Subspecies. III. Discussion." Annals of the Carnegie Museum 41(4): 45-168.

Silva, Gilberto Taboada, William Suárez Duque, and Stephen Díaz-Franco. 2007. Compendio de Los Mamíferos Terrestres Autóctonos de Cuba. Vivientes y Extinguidos. La Habana: Boloña.

Smith, Krister T, and Carlos A. Scanferla. 2016. "Fossil Snake Preserving Three Trophic Levels and Evidence for an Ontogenetic Dietary Shift." Palaeobiodiversity and Palaeoenvironments 96(4): 589-599.

Steadman, David W. et al. 2015. "Vertebrate Community on an Ice-Age Caribbean Island." Proceedings of the National Academy of Sciences 112(44): E5963-71.

Steadman, David W et al. 2007. "Exceptionally Well Preserved Late Quaternary Plant and Vertebrate Fossils from a Blue Hole on Abaco, The Bahamas." PNAS 104(50): 1989719902.

- - . 2014. "Late-Holocene Faunal and Landscape Change in the Bahamas." The Holocene 24(2): 220-30.

Steadman, David W, Gregory K. Pregill, and Storrs L Olson. 1984. "Fossil Vertebrates from Antigua, Lesser Antilles: Evidence for Late Holocene Human-Caused Extinctions in the West Indies." Proccedings of the National Academy of Science 48: 4448-51. 
Stephenson, N. G. 1960. "The Comparative Osteology of Australian Geckos and Its Bearing on Their Morphological Status." Journal of the Linnean Society of London, Zoology 44(297): 278-99.

Stephenson, N G, and Elsie M Stephenson. 1956. "The Osteology of the New Zealand Geckos and Its Bearing on Their Morphological Status." Transactions and Proceedings of the Royal Society of New Zealand 84(2): 341-58.

Suárez, William. 2004. "Biogeografía de Las Aves Fósiles de Cuba." In CD. Origen y Evolución Del Caribe y Sus Biotas Marinas y Terrestres, ed. Manuel Iturralde-Vinent. La Habana: Centro Nacional de Información Geológica, 1-17.

Thomas, Richard, and S. Blair Hedges. 1998. "A New Amphisbaenian from Cuba." Journal of Herpetology 32(1): 92-96.

Torres-Carvajal, Omar. 2003. "Cranial Osteology of the Andean Lizard Stenocercus Guentheri (Squamata: Tropiduridae) and Its Postembryonic Development." Journal of Morphology 255(1): 94-113.

Torres, Javier L., Tomás Michel Rodríguez-Cabrera, and Rubén Marrero Romero. 2017. "Reptiles." In Diversidad Biológica de Cuba: Métodos de Inventario, Monitoreo y Colecciones Biológicas, eds. Carlos A. Mancina and Daryl. D. Cruz. La Habana: Editorial AMA, 376-411.

Uetz, P, P Freed, and Jirí Hošek. 2018. "The Reptile Database." http://www.reptiledatabase.org (December 2, 2018).

Varona, L S, and O Arredondo. 1979. "Nuevos Táxones Fósiles de Capromyidae (Rodentia: Caviomorpha)." Poeyana 195: 1-51.

Vasilyan, Davit, Vladimir S. Zazhigin, and Madelaine Böhme. 2017. “Neogene Amphibians and Reptiles (Caudata, Anura, Gekkota, Lacertilia, and Testudines) from the South of Western Siberia, Russia, and Northeastern Kazakhstan." PeerJ 5: e3025.

Villa, Andrea, Juan D. Daza, Aaron M Bauer, and Massimo Delfino. 2018. "Comparative Cranial Osteology of European Gekkotans (Reptilia, Squamata)." Zoological Journal of the Linnean Society XX: 1-39.

Wagler, Jean G. 1830. Natürliches System Der Amphibien, Mit Vorangehender Classification Der Säugetiere Und Vögel. Ein Beitrag Zur Vergleichenden Zoologie. München: Stuttgart, and Tübingen.

Zaher, Hussam, and Olivier Rieppel. 1999. "Tooth Implantation and Replacement in Squamates, with Special Reference to Mosasaur Lizards and Snakes." American Museum Novitates 3271: 1-19.

Zaher, Hussam, and Carlos A. Scanferla. 2012. "The Skull of the Upper Cretaceous Snake Dinilysia Patagonica Smith-Woodward, 1901, and Its Phylogenetic Position Revisited." Zoological Journal of the Linnean Society 164(1): 194-238.

Zangerl, Rainer. 1945. "Contributions to the Osteology of the Post-Cranial Skeleton of the 
Amphisbaenidae." The American Midland Naturalist 33(3): 764-80.

Zheng, Yuchi, and John J Wiens. 2016. "Combining Phylogenomic and Supermatrix Approaches, and a Time-Calibrated Phylogeny for Squamate Reptiles (Lizards and Snakes) Based on 52 Genes and 4162 Species." Molecular Phylogenetics and Evolution 94, Part B: 537-47. 